\title{
The Tourism Students' Awareness of Communicative Competence in an English as a Foreign Language Context
}

\author{
Ercilia Loera Anchondo, PhD \\ Autonomous University of Ciudad Juarez, Mexico
}

Doi: 10.19044/esj.2018.v14n5p184 URL:http://dx.doi.org/10.19044/esj.2018.v14n5p184

\begin{abstract}
The present research aimed to find out the students' awareness towards the concept of communicative competence and to discover if exposure serves as a tool in the development of the latter. Applying a mixed-method research design, quantitative and qualitative data were gathered with three different instruments: a face-to-face questionnaire, a semi-structured interview, and a structured observation. The subjects consisted of forty-six English as a Foreign Language learners in the intermediate and advanced levels in the Tourism major at the Universidad Autónoma de Ciudad Juárez. Eleven questions were designed to find out the students' awareness on communicative competence and its components. The interview was based on the elements of communicative competence and the activities related to exposure to the target language. The observation considered details in regards to the students' performance in the linguistic and pragmatic components of communicative competence. Results indicated that participants are aware of the concept under study and its components. Their answers to the interview and their performance in the observation proposed that exposure to the target language have been used towards the development of certain elements in their communicative competence. Recommendations derived from the present study include making students comprehend what the acquisition of a communicative competence encompasses, which is to manage the target language through the use of the four skills. Secondly, it is of great importance to promote in students the habit of practicing the target language outside the classroom. Finally, it is necessary to pay attention to phonological features such as word stress, pitch, and intonation to improve pronunciation.
\end{abstract}

Keywords: Communicative competence, tourism, EFL 


\section{Introduction}

As mentioned by Fang (2010), English language has become a global or international language within a globalization context in the current century. Due to its position as a lingua franca, it is the main foreign language used worldwide as a tool of communication. This situation has led to in-depth studies regarding the English language terrain placing emphasis on learnercentered approaches. In the English as a Foreign Language (EFL) field, increasing attention has been focused on communicative competence (CC) over recent years. This approach has played an important role in language teaching and learning since language is used for communicative purposes, and communication involves more than knowing accurate language forms. The development of a communicative competence constitutes the core of learning a language. Although the concept previously mentioned is of great relevance to the language area, analysis on the awareness and performance by EFL learners in this term stills requires attention. EFL learners are not entirely aware of what the concept of communicative competence entails and consequently, they are not able to identify the elements in situations that they would help them to develop it. For example, it is known that being able to communicate in a colleague's language, as in the specific case of speaking English, helps in better job negotiations as well as social interactions. Considering the roles that Universidad Autónoma de Ciudad Juárez (UACJ) students play in the labor market when they graduate, they may interact with people from around the world that speak English; for this reason, they need to communicate in the target language to perform their jobs. Although this is a reality, it is known that learners and professionals working in the tourism sector are not proficient in English. In respect to this, Hrehová (2010) highlights the importance of a communicative competence in EFL learners in terms of correct expression of ideas when communicating with different type of personnel at work. In addition, Wilson \& Sabee (2003) point out the need of a consensual agreement on what constitutes communicative competence.

Communication and language competences in English today represent an indispensable attribute of working positions related to Tourism. Without the correct expression of thoughts and communication, work tends to be less efficient, especially when an employee is unable to present his thoughts, ideas or comments and communicate correctly not only with his superiors, but also with colleagues and business partners. Communication competences also imply professional and representative conduct. Employers today are assuming that university graduates will have mastered these competences.

The EFL teaching is a relevant element in this issue. Nowadays, The English program in the Tourism major at UACJ highlights the importance of English to convey communicational purposes; however, it is necessary to obtain information about students' awareness of communicative competence 
and to identify the elements that help EFL learners to develop it outside the classroom. Based on these considerations, the objectives of the present study are the following:

- $\quad$ To analyze to what extent EFL learners in the Tourism major are aware of the concept of communicative competence.

- $\quad$ Based on learners' perspectives, to identify the elements or aspects of language to develop communicative competence during the exposure to English.

\section{Literature review}

This section will address concepts and theories that will provide the theoretical basis for the subject under study. Definitions such as of English as a foreign language, as well as the concepts of communicative approach, linguistic, pragmatic, and communicative competence will be explained.

\section{English as a Foreign Language}

Languages can be used and studied depending on the linguistic role they have among individuals. For example, English is commonly listened to, spoken, read and written as a foreign language in numerous countries. SavilleTroike (2005) mentions in a general fashion that a foreign language is the one that is not used by speakers in their natural context. However, Bahumaid (2012) states that a foreign language context is given when that language is used among speakers with the purpose of using it for exchanges with "outsiders" such as the situation of English in China and Egypt.

\section{Exposure in the target language}

A second concept to be considered is exposure. The British Council (2006) explains that exposure has to do with the contact the learner has with the target language outside the classroom. Similarly, MacLeod \& Larsson (2011) conclude that the language outside the classroom refers to the different components that the language learners are exposed to off-campus. As an illustration, watching TV or reading a book in English are examples of the language outside of the classroom. In this aspect, Gilakjani (2012) conceives exposure not only when students are in contact with the foreign language in common daily situations, but it also includes the amount of instruction received in that language in the past.

\section{Communicative Approach}

Thirdly, communicative competence can be developed by considering perspectives such as what is known as the communicative approach (CA). In this respect, Anthony (1963) defines approach as "a specification of the assumptions and beliefs about the nature of language and language learning" 
(as cited in Bahumaid, 2012). Regarding CA, some of its characteristics are the following: the goal is that learner communicates in the target language, students work in groups to transfer meaning in situations, the teacher operates as a facilitator, and students practice in role-plays and dramatizations (CelceMurcia, Brinton, and Snow, 2014). In addition, for Canale and Swain (1980) communicative approach encompasses the communicative functions (asking for a favor, complaining, and apologizing) that a learner should know considering the usage of the grammatical forms to express these functions appropriately.

\section{Communicative Competence}

The term competence goes along with the concept of performance, which is the reason why it is pertinent to define the second one as well. Firstly, "performance" was introduced by Chomsky (1965) as the use of the language in any kind of situations. On the other hand, "competence" is what the author referred to as the knowledge a speaker has about language. He claimed that competence involves grammar or linguistic knowledge of the language a speaker needs to have in order to perform appropriately in a speech community (as cited in Canale and Swain, 1980). Conversely, Hymes (1962, as cited in Shinde \& Shavan, 2013) points out that communicative competence includes other kind of competences such as sociolinguistic and contextual. In this sense Shinde and Shavan (2013) provide some definitions about what communicative competence means. In general, they emphasize the fact that a communicative competence needs to be achieved in an appropriate and effective manner through speaker-interaction.

\section{Linguistic Competence}

One of the main aspects involved in the acquisition of a second language is the linguistic competence. Chomsky (1962, as cited in Shinde \& Shavan, 2013) argues the idea that there is a linguistic competence referring to the inherent grammatical knowledge of a speaker. At variance with this, Fisher (1984) defines it as “...the learner's knowledge of the structures and vocabulary of the language and his ability to produce and comprehend wellformed sentences in the language" (as cited in Nouar, n.d., p. 4). These notions of linguistic competence are an important contribution to understanding language learning. For Celce-Murcia, Dörnyei, and Thurrell (1995) this competence consists of the essential components of communication: types and patterns of sentences, the morphological inflections, the constituent structure and the lexical repertoire; the phonological and orthographic systems are also considered (cf. Celce-Murcia \& Larsen- Freeman, 1983; Celce-Murcia, Brinton \& Goodwin, in press). 


\section{Pragmatic Competence}

Finally, another central element for English proficiency is pragmatic competence. Taguchi (2009, as cited in $\mathrm{Hu}, 2014$, p. 391) defines it as "the ability of a second language or a foreign language learner to use the target language appropriately in corresponding social contexts". On the same subject, Rodriques (2000) refers to the illocutionary competence as part of the pragmatic competence. The illocutionary competence relies on the Speech acts theories from some authors such as Austine (1962) and Searle (1969), as well as Halliday's $(1973,1976)$ description of language functions. Rodriques lists four main categories related to functions: the ideational (to convey meaning of real world); the manipulative (use of language to affect the surround speakers); the heuristic (using the language to increase one's understanding of the world); and, the imaginative function (creative use of language to create atmosphere). At this point it is pertinent to make reference to pragmatics. Based on Crystal's (as cited in Kasper 2001) definition, Mitib, (n.d.) defines it as "the study of communicative functions in its sociocultural contexts". These communicative functions, according to Kasper (2001) not only encompasses the speech acts such as apologizing or requesting, but also different types of discourse and speech events of changing length and difficulty (as cited in Mitib, n.d.). As can be seen, Crystal and Taguchi's definitions agree on the importance of enhancing language interaction with others in social situations. This notion about language relates to how Vygotsky conceived it. Language was for communication purposes and it was elaborated from social interactions (as cited in McLeod, 2014).

\section{Methodology}

This study employed a mixed method approach considering a sequential explanatory design to find out the extent to which EFL learners are aware of the concept of $\mathrm{CC}$, as well as, discover if exposure to the target language serves as an element for the development of a CC. This section gives a detailed account of the instruments, participants and procedures utilized in this study.

\section{Instruments}

In this study, three types of instruments were applied: a face-to-face questionnaire, a semi-structured interview, and a structured observation, all of which are presented as follows.

\section{Face-to-face questionnaire}

In order to determine the students' awareness on the concept of communicative competence, a face-to-face questionnaire was administered. The research question which this tool helped to answer was to what extent are 
EFL learners aware of the concept of communicative competence? The questionnaire was divided in two parts. The first part consisted of the students' general information such as age and proficiency level. The second part included eleven statements with a Likert-type scale supplemented by five options: strongly agree, agree, neither agree nor disagree, disagree, and strongly disagree. The aspects to be under study through questions \# 3, 4,5, 6 , and 7 were related to students' understanding of communicative competence taking into consideration the mastering of the four language skills. Items 8, 9 and 10, dealt with students' awareness on linguistic competence. Item 8 referred to grammar rules, item 9 alluded to syntax, and item 10 gauged vocabulary repertoire. Questions 11, 12 and 13 were designed to get information about the pragmatic competence. In this case the communication functions related to the tourism sector were included as indicators to determine, from the students' perspective, about an individual's English communicative competence. The functions under study were giving information to a tourist, providing a service, and solving a problem to visitors. The questionnaire was designed in Spanish to avoid any kind of misunderstanding from the participants.

\section{Interview}

A face-to-face, semi-structured interview was conducted to obtain data about the students' perceptions and experiences on the ways exposure to the target language has played a role in their communicative competence development. The research question that this instrument attempted to give a response to was how can exposure to the target language be used to develop a successful communicative competence in EFL learners? The design of the questions was based on the elements of communicative competence and activities related to exposure to the target language outside the classroom.

\section{Structured observation}

A non-participant, structured observation was used to examine the students' communicative competence in a specified task. This instrument was also utilized to answer the previously mentioned question about how can exposure to the target language be used to develop a successful communicative competence in EFL learners? The observation was chosen considering the details it provided in regards to the students' performance in the linguistic and pragmatic components of communicative competence.

\section{Participants}

The target sample for this research was college students currently enrolled in the Tourism major at UACJ. The participants were forty-six learners taking English classes from the Communicative English Program, 
which was recently implemented in 2015. Students exclusively in the intermediate and advanced levels who had had exposure to the target language were taken into account. Other criteria for this selection were that these learners had gone through a more extensive process of developing their communicative competence and had been exposed to the language in more numerous ways. The number of participants from intermediate level was eighteen from a total of nineteen, and from the advanced level the twenty-eight students registered in the class were part of the study.

\section{Procedure}

Conducive to collect data, the instruments were applied in a general to specific fashion. Firstly, the questionnaire was piloted, and threats such as ambiguity, technicalities and loaded questions were revealed. Then, modifications were made based on a restructuration of questions in regards to wording, distribution, and coherence. Questionnaires were revised by professors from both the Communicative English program and the Tourism major. The final version was applied to forty-six intermediate and advanced EFL students. The study was carried out in classrooms at the Social Science and Administration Institute within the UACJ facilities. Secondly, a semistructured interview was conducted for an average of about twenty minutes for each person. In total, four interviewees, two from the intermediate level and the other two from the advanced level, were asked to talk about their perceptions on their communicative competence by being exposed to the target language. Finally, for the structured observation, the same four students who participated in the interview were requested to hold a casual conversation with a classmate and later with a stranger (English native speaker) to get to know each other better. The observations allowed to analyze the interactions and evident aspects of communicative competence in the students' performance.

\section{Results}

Data collected are displayed in two sections. The first part presents quantitative data that reflect the findings obtained from the questionnaire applied to students. Subsequently, the major themes derived from the interviews and the observations are analyzed in the qualitative segment.

As it was mentioned before, the student questionnaire consisted of two sections. The first one was designed to obtain general information about the participants. Section 2 included questions regarding three aspects of communicative competence, each of which is presented and discussed in detail below. 


\section{Quantitative data}

Concerning the data gathered from section 1 , it was found that the sample consisted of twenty-six females and twenty males. In relation to their level of English, eighteen students were in the intermediate level of English and twenty-eight learners were in an advanced course.

Results obtained from the second section regarding students' perceptions about English language competence are presented as follows:

Figure 1 presents the results from item 3 in the questionnaire regarding the communicative competence awareness. Students' responses revealed that they concurred with the idea that being competent means using the four language skills. It can be noticed that $73.91 \%$ (34) of the students strongly agreed, while $19.56 \%$ (9) coincided with this notion. In contrast, none of the students selected the options "neither agree nor disagree" in the questionnaire. Moreover, $6.52 \%$ (3) of the students strongly disagreed with the statement in item 3.

In relation to the students' awareness of communicative competence taking as reference the mastering of the four language skills, the following findings were obtained: Figure 2 shows that speaking (item 4) is considered as a decisive ability to determine if a person is competent in English. Values taken from "strongly agree" and "agree" options demonstrate that $93.46 \%$ concurred with this idea, while $6.52 \%$ neither agreed nor disagreed. As can be observed, no one opposed to it. A similar pattern is found in item 5 that refers to listening skill: $86.95 \%$ of the participants thought that understanding spoken English was an indicator of being competent in the target language. It is noticed that only $4.39 \%$ neither agreed nor disagreed, and there was only $8.69 \%$ of the sample that strongly differed on this matter. Concerning reading (item 6), it was found that $76 \%$ of students perceived that this is another crucial ability to develop; only five participants $(10.86 \%)$ expressed the opposite and $13 \%$ remained neutral in their posture. Finally, the aspect of writing addressed in question 7 is not considered as meaningful as the other skills in terms of language competence. The same figure shows that only $67.38 \%$ of the sample agreed that being proficient in writing is an indicator of possessing the capability of communicating successfully in the target language. Only $15.21 \%$ of the students had no opinion about it. The percentage of participants that differed on the same point was 17.39. 
Figure 1. Students' awareness of the concept of communicative competence

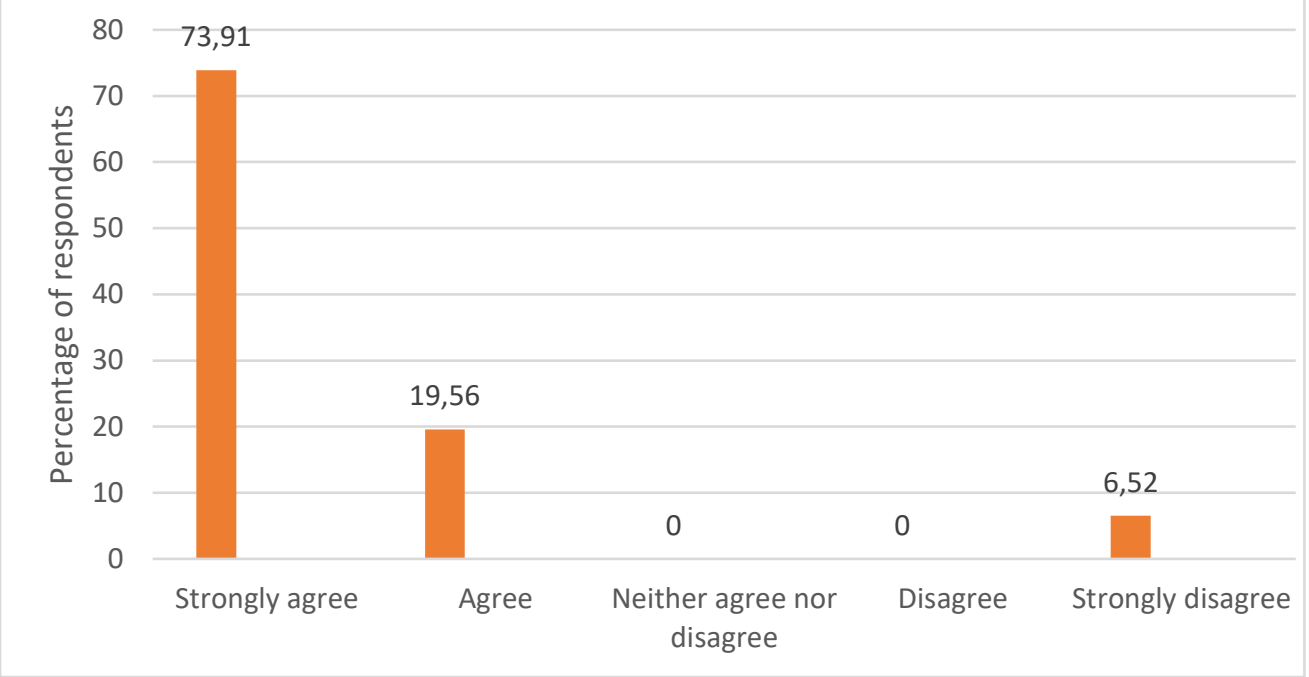

Figure 2. Students' awareness of communicative competence by considering language skills

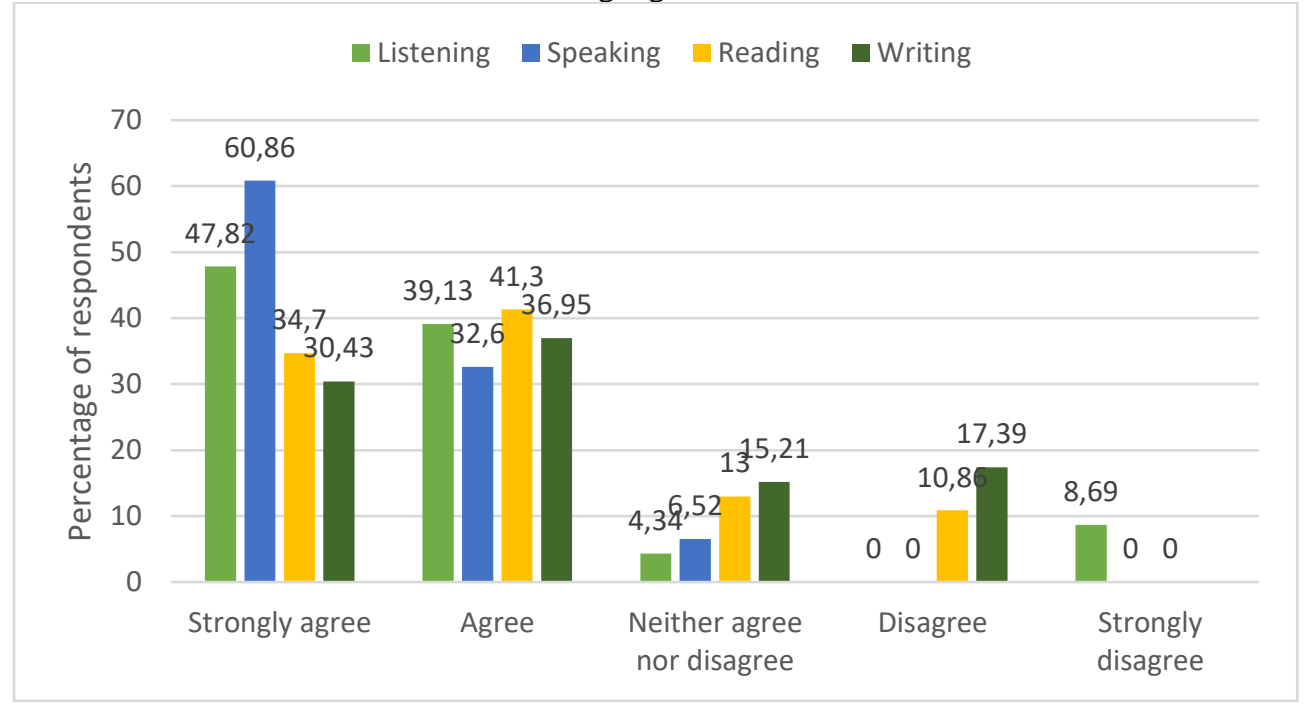

Regarding the awareness on the elements of linguistic competence, figure 3 shows the results from items 8, 9, and 10 in the questionnaire. Students' responses to item 8 towards one of the elements of linguistic competence which encompassed grammar, revealed that they considered it to be moderately significant in the use of English. It can be observed $15.21 \%$ of the students strongly agreed with the fact that to be competent in English, they need to know how to use grammar rules accurately. In addition, 36.95\% coincided with this notion. In contrast, $34.78 \%$ of the respondents selected the 
neutral point in the scale. Moreover, the choices of "disagree" and "strongly disagree" obtained the same value of $6.52 \%$, that is 3 participants from the sample.

Figure 3. Students' awareness on the elements of linguistic competence

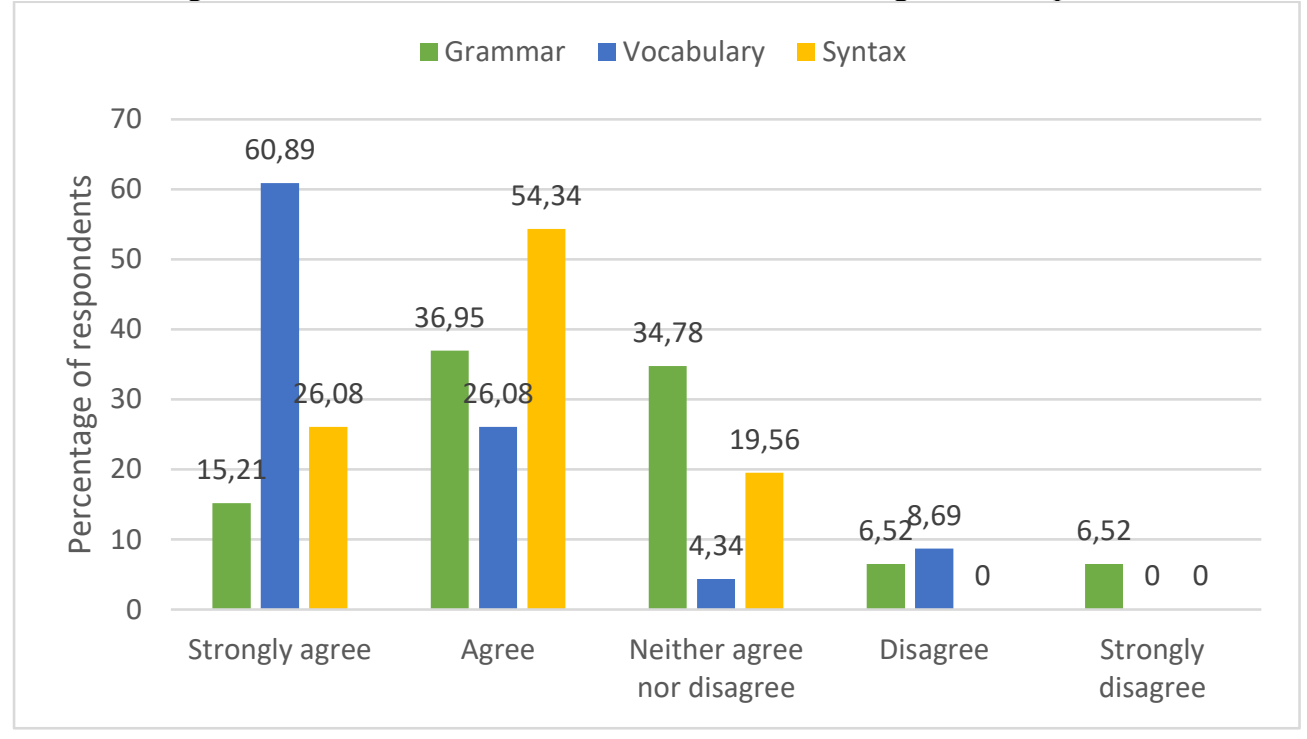

The linguistic element to analyze in item 9 was vocabulary usage. It was found that $60.89 \%$ (28) of the students strongly conceived vocabulary usage as part of communicative competence. Furthermore, 26.08\% (12) of the respondents agreed with this concept. In contrast, only $4.34 \%$ of the students had no a strong opinion one way or the other, whereas $8.69 \%$ didn't perceive vocabulary usage as an element to be competent in English.

Finally, item 10 gauged the syntax aspect on the linguistic competence. A percentage of 26.08 strongly coincided with the idea that mastering sentence structure (know how to place subject, verb and object in the correct order) is needed to be competent in the language. In addition, 54.34\% (25) agreed with the same view. As can be observed, a percentage of 19.56 responded with the option of the mid-point in the Likert scale. The value for "disagree" and "strongly disagree" was 0 .

The last section under study in the questionnaire was the students' awareness in relation to the components of pragmatic competence in the field of tourism. Data gathered from items 11, 12 and 13 are shown in Figure 4. The results revealed that students are conscious of some of the components of pragmatic competence. In item 11, the component that was analyzed was the ability to give information to a tourist. It was found that students agreed with the notion that providing information to visitors is an indicator of being competent in English. A percentage of 56.52 of the students strongly agreed, 
while $32.60 \%$ (16) of the participants coincided with this idea. However, only $10.86 \%$ of the students remained neutral in their opinions.

Furthermore, responses in item 12 followed a similar pattern. Knowing how to provide a service in English to tourists was the pragmatic to be examined. It was found that the majority $(95.63 \%)$ of students marked "strongly agree" and "agree" in the Likert scale. This percentage of participants leans towards the idea that being able to give a service to a visitor in the target language is a benchmark to determine how competent that person is in English. However, both options "neither agree nor disagree", and "disagree" from the questionnaire received only $2.17 \%$ of the responses from the students.

Figure 4. Students' awareness on the components of pragmatic competence

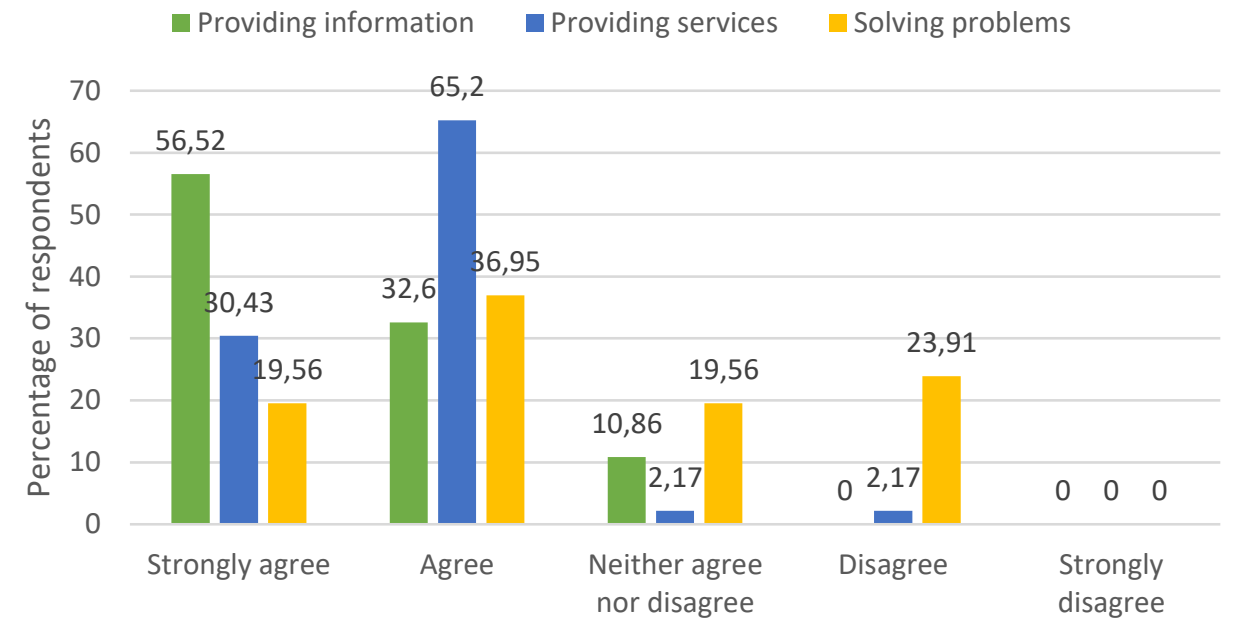

On the contrary, item 13 received different responses from questions 11 and 12. The pragmatic element to be studied was the ability to solve a problem to a tourist using English language. Taking into account the values on both "strongly agree" and "agree" options, findings show that only $56.51 \%$ (26) of the participants considered that a person communicates successfully in English if he/she overcomes a difficulty a tourist may face. It is noticed that $19.56 \%$ had no opinion about this idea. However, $23.91 \%$ (11) of the respondents differed with this view. The value for "strongly disagree" was zero in the three pragmatic competence items.

\section{Qualitative data}

Information related to the learners' opinions towards the relationship between exposure to the target language and the development of a communicative competence is presented in this section. As it was mentioned before, a semi-structured interview and a structured observation conducted 
with two intermediate and two advanced-level students were carried out for that purpose. The results obtained are reported in the following categories.

\section{Importance of learning English}

In relation to the learners' opinion of English in their areas of expertise, all of the interviewees considered that the foreign language represents an essential element in their academic and professional growth. They considered that it was a smart decision to include the English subject as a mandatory course. They expressed that learning English added a plus to become good professionals. As one of the participants explained: "Knowing how to speak a foreign language is very important in our profession, especially English because, here on the border we receive tourists mainly from the United States and other countries that use this language to communicate."

\section{Exposure to the language}

When asked about their time being exposed to the language, interviewees had similar responses, mentioning that they had had a certain type of contact with English for more than ten years. Living on the border allowed them to be in contact with English. Watching TV shows and listening to music in English, as well as visiting El Paso, Texas were relevant activities that helped develop language skills. All of them pointed out that without having had any type of exposure, they would not have the same language performance as they currently do.

\section{Grammar}

During interviews, students' comments on the questions regarding grammar mainly reflected a characteristic. The mentioned feature was that students considered exposure as an element involved in their learning of word order and sentence structure; despite this fact, they thought their knowledge on grammar was by reason of attending English classes. These remarks were confirmed by the event focused observation since the majority of students used prefabricated expressions commonly taught in class.

\section{Phonology}

Concerning this aspect, each student expressed a positive view commenting that his or her pronunciation was acceptable. However, in addition to this, most of the students emphasized that their pronunciation was a necessary feature of the language in which they still needed to work. The students' responses were parallel with what was observed, making evident that word and sentence stress, as well as pitch and intonation were the aspects where students have to practice more. 


\section{Vocabulary}

A major category that clearly emerged in every interview was the learners' opinion about their vocabulary repertoire and use. They believed that they did have problems with their vocabulary. As a matter of fact, they thought that their vocabulary was not vast and proper. These comments were confirmed by the structured observation. Learners limited their communication because their vocabulary repertoire was not ample enough to express their ideas. They were using words in Spanish because they could not find their equivalent in English. The acquisition of vocabulary is perceived as a challenge because the numerous words to be learned in both informal environments and in their professional context.

\section{Register appropriateness}

Moreover, the interview data revealed that students were very aware of the differences among taking part in a conversation with someone from another group of people such as: a teacher, boss, or strangers. They mentioned that when talking in a formal situation, language was linked to correctness, respect, professionalism, and conciseness; while in an informal situation, they explained that they felt relaxed and could participate more in the process of communication. These opinions about an upper level of formality were evident through the observation of a conversation with a native English teacher where students notably used different vocabulary, had a distinct body language, and paid special attention to their production. At the same time, students having a relaxed and less structured conversation with a classmate demonstrated comments on an informal level.

\section{Language function}

An element with reference to the students' pragmatic competence was identified during the observation. It was found how rapidly the vast majority of participants adapted themselves to the language function. During the observation, it was notable that participants distinguished and chose the purpose of their communication such as giving information, apologizing, maintaining or asking for permission. They followed a sequence in their segments of the conversations that demonstrated the interactional function of language where they introduced themselves, asked, and answered questions.

\section{Language comfort}

Another aspect that emerged in most of the interviews is how students felt using English. Students indicated that they felt satisfied with their performance in their classes because it fulfilled their purpose of learning English. The majority of them agreed with the idea of feeling comfortable using the language with their peers in the classroom. It was found that they 
felt free to use the language whenever they had the opportunity to take part in a conversation with their classmates or with their teachers. On the contrary, students mentioned they felt insecure and overwhelmed when talking to strangers or people with a higher level of proficiency in English. With the observation, when talking to other students, their comfort was noticeable; on the other hand, when having a conversation with a more proficient person, their body language and attitude changed towards that person.

\section{Exposure activities}

Another finding the interviews revealed was the type of activities students use to expose themselves to real language. The most predominant activities students mentioned were YouTube videos, blogs, books, music, Facebook, movies, and TV shows. In the case of books, students pointed out that extensive reading helped them to increase their vocabulary repertoire because they could clearly see how the words were used in real context. In addition, students referred to music as the main tool or source they use to learn pronunciation.

\section{Autonomy}

Autonomy was another aspect closely related to exposure and communicative competence. Most of the students indicated that they learned more things from the language while being exposed because they knew what to do when confusion about vocabulary, pronunciation, grammar or culture arose. Along with this, they also commented that there was a certain type of control of their own learning when they chose the activities of their interest to practice English instead of going to the class to work there.

\section{Discussion}

The findings in this research showed there is a type of awareness towards the concept of communicative competence and its components in intermediate and advanced-level students. This awareness had helped them to keep interest in learning English because they are conscious of the relevance and impact it has in their academic performance in the major they are currently pursuing. It was found that learners positively supported the definition of the concept suggested by Yufrizal, 2014. In his words, communicative competence is "the language user's grammatical knowledge of syntax, morphology, phonology and the like, as well as social knowledge about how and when to use utterances appropriately" (p. 26). Similarly, Hymes (1962, as cited in Shinde \& Shavan, 2013, p. 153) proposed that a model for communicative competence includes a grammatical, sociolinguistic and contextual competence. The viewpoints from the students represent that it is clear to them that a communicative competence in the language entails not 
only knowing about it, but also using it through interaction with others considering Hymes' elements as well.

In relation to the linguistic competence, students showed they did have a clear idea of what this competence consists of. Their notions are in accordance with Celce-Murcia \& Larsen-Freeman, 1983; Celce-Murcia, Brinton \& Goodwin, in press, who consider the types of sentences, the composition and word order, and the vocabulary, as well as the phonological and orthographic structures as essential elements for this kind of competence (as cited in Celce-Murcia, Dörnyei, and Thurrell, 1995 p. 16-17).

To continue, results regarding another component of the linguistic competence, which is vocabulary knowledge and usage, demonstrated that students find significantly important in their communicative competence to have a wide repertoire of vocabulary and to know how to use it in a conversation. Getting vocabulary is perceived as a difficult task to accomplish. These results were to a certain extent similar to those of Yufrizal's (2014) students commented on vocabulary as a burdensome learning process.

In reference to the pragmatic components of communicative competence, findings indicated that there is an acceptable level of awareness towards this type of elements. Their responses agreed that giving information to a tourist and providing a service to visitors are aspects to have as part of a pragmatic competence; however, for students solving a tourist's problem is not as relevant as the other two functions. These tasks are related to the manipulative kind of function mentioned by Rodriques (2000) which consists of using of language to affect the surround speaker. Nevertheless, features of the rest of the functions (the ideational, the heuristic and the imaginative) listed by the author were not considered by students. The learners' ideas on pragmatic competence clearly relate to the definition provided by Taguchi (2009, as cited in $\mathrm{Hu}, 2014$, p. 391) who mentioned that this competence is "the ability of a second language or a foreign language learner to use the target language appropriately in corresponding social contexts". Similarly, students considered aspects of pragmatic competence such as the communication function, level of formality, and register appropriateness when they were communicating in English. These results were in line with those from Yufrizal (2014), which showed that students believed that they were able to accomplish all kinds of language functions such as greeting, apologizing, and talking to strangers, along with others.

Taking into consideration the results that reflected the importance of learning English in the learners' responses, participants considered English as an essential element in their academic and professional growth, and in their everyday use. These findings were against the ones presented in a study by Fang (2010), which showed that most students considered English only as a requirement to pass their classes and get a better job in the future. Moreover, 
findings related to the Tourism students' awareness on the communicative competence indicated that they strongly agreed with the concept of communicative competence as knowing the language and using it through the four skills (listening, speaking reading, and writing skills). These results were to a certain extent similar to the ones presented in Fang (2010), who found out that college students from China were not familiar with the English concept of the communicative competence, but they comprehended what the CC highlights. In addition, most of them only emphasized the importance of the speaking ability, while results in the present study considered speaking, listening and reading as crucial skills to develop. Participants from both studies did not perceive writing as a relevant aspect in their English competence.

Results in relation to exposure to English proposed that students agree that without any type of exposure to the target language, they would not have the same language performance as they do in the present time. Participants perceived it as a reinforcing tool to improve their vocabulary, pronunciation, and conversational strategies. They shared that their exposure activities are: YouTube videos, blogs, books, music, Facebook, movies, and TV shows, which give an account of what exposure encompasses. The British Council (2006) explained that exposure has to do with the contact the learner has with the target language outside the classroom. Even when students admitted that elements of their communicative competence had been acquired due to their exposure, there were still parts that as it was acknowledged by Gilakjani (2012) English language learners have to emphasize, such as the aspect of pronunciation. He views pronunciation as a key element in the development of communicative competence.

Regarding performance, students commented on the interviews that speaking and conversation skills are part of it. They commented that their productive skills incremented more than receptive skills by exposing themselves to real language. This finding differs from the results in the study by Bueraheng and Laohawiryanon (2014), in which students' receptive knowledge was higher than their productive knowledge. Even though their productive skills such as writing and conversation increased noticeable for them, they still consider themselves more proficient in receptive skills. In a like manner, findings on the same matter revealed that the most predominant exposure activities students participate in are movies, TV shows, and social media. On account of this, students mentioned that these distractions help them to reinforce what they learn in class. These findings were in agreement with the study conducted by Candilas (2016), in which it was discovered that watching movies and television programs in English was among students' favorite activities to be exposed to. Similarly, the author found that informal exposure plays an important role in the development of the learner's speaking 
skill; however, he points out that both formal and outside environments as well as other factors contribute to speaking proficiency.

Finally, results in this study lead to emphasize the benefits for foreign language learners to develop a communicative competence in English. It was found that in this case, by creating consciousness about the concept of communicative competence, language learning could be promoted among students. If students are well informed that developing a communicative competence is the real purpose of learning English, learner can gain more confidence to become a bilingual learner. Another aspect derived from this study is to create awareness of the real outcome of learning a language, which is to be competent in English. Results indicated the significant role of creating consciousness about implementing the learning of the four skills in English courses. It is crucial students comprehend what the acquisition of a communicative competence encompasses, which is to manage the target language through the use of the four skills (speaking, writing, listening, and reading). Additionally, it is pertinent to point out that communicative competence is to a certain extent attached to the level of exposure learners have in the target language and the type of activities define as well their English competence and performance. In this sense, Larsari (2011) alludes to the need of including authentic materials to develop this aspect of language and proposes the use of computer mediated communication tools to enhance $\mathrm{CC}$. The findings raise questions and issues for further research such as discovering what specific exposure activities can help students to develop each of the components in communicative competence.

Regarding English teachers, information obtained from this study can make instructors aware of the expected outcome in English classes. This outcome is for students to be functional in a language, which is a part of what the concept of communicative competence encompasses. Therefore, by creating also consciousness in teachers about this topic, they will include not only conversation strategies in their classes, but also other components of the communicative competence required to be proficient in English. As a result, English classes will have a more straightforward purpose and will be more effective. In a like manner, findings can draw attention in teachers about the two main components that characterize a communicative competence which are the pragmatic and the linguistic aspects and how to promote in their courses. Lastly, results shed light on a deeper understanding of the role of exposure used in a learning atmosphere in constructing a communicative competence. It is of great importance to promote in students the habit of practicing the target language outside the classroom and include a wider variety of exposure activities in their daily practice. 


\section{Conclusion}

Communicative competence is the prime pursued objective of language learning and teaching. The present research investigated the awareness of the concept of communicative competence by EFL learners and how exposure can help in the development of the mentioned. The results showed that there is a positive degree of awareness on the concept. Students' responses revealed that they agreed with the idea that being competent means using the four language skills. However, speaking and listening are considered decisive abilities to be proficient in English. In relation to the linguistic aspect, it was found that vocabulary and syntax are conceived as the most important elements to be mastered in order to be competent in the language. In reference to the pragmatic view, it was discovered that students are conscious about the importance of developing two abilities in the field of tourism: giving information and knowing how to provide a service to a visitor. These functions are perceived as crucial indicators of being competent in the target language. Similarly, it was discovered that learners recognize and present the ability to use language appropriately for different purposes, registers, and social situations. In addition, it was demonstrated that exposure facilitates the linguistic and pragmatic components in the development of learners' communicative competence. In a like manner, it was revealed that the phonological features such as word stress, pitch, and intonation remain to be mastered. Here, it was mentioned that vocabulary repertoire and use was vast and proper; however, it was observed that there is a limited use of vocabulary when maintaining a conversation. Findings also unveiled the students' positive attitude towards exposure in their language learning. Further analysis on this matter can focus on discovering what types of exposure activities can help students to increase each of the abilities required to have a successful communicative competence in English. As a final comment, developing communicative competence should be a mandatory element for EFL learning in colleges and universities and should be a priority when teaching and learning English nowadays.

\section{References:}

1. Ajileye, S. (1998). The Effect of Exposure to English Language activities outside the classroom on Written English: a Study of Selected Secondary Schools in Ilorin. Department of Modern European Languages, University of Ilorin, Nigeria. Retrieved from http://www.unilorin.edu.ng/journals/education/ije/sept1998/

2. Bahumaid, S. A. (2012). The Communicative Approach in EFL Contexts Revisited. International Journal of Social Science and Humanity, 2, 446-448. doi: 10.7763/IJSSH.2012.V2.143 
3. British Council. (2006, March 10). Exposure. Retrieved from https://www.teachingenglish.org.uk/article/exposure

4. Bueraheng, N., \& Laohawiryanon, C. (2014). Does learners' degree of exposure to English Language influence their collocational knowledge? International Journal of English, 4, 1-10. Retrieved from: https://www.academia.edu/7700468/DOES_LEARNERS_DEGREE_ OF_EXPOSURE_TO_ENGLISH_LANGUAGE_INFLUENCE_TH EIR_COLLOCATIONAL_KNOWLEDGE

5. Canale, M., \& Swain, M. (1980). Theoretical Bases of Communicative Approaches to Second Language Teaching and Testing. Applied Linguistics, 1, 1-47. doi: 10.1093/applin/I.1.1

6. Candilas, K. (2016) Language Exposures: Determinants of English Speaking Proficiency. Veda's Journal of English Language and Literature- JOELL, 3(3), 52-60.

7. Celce-Murcia, M., Dörnyei, Z., \& Thurrell, S. (1995). Communicative Competence: A Pedagogically Motivated Model with Content Specifications. Issues in Applied Linguistics, 6, 5-35. Retrieved from http://escholarship.org/uc/item/2928w4zj

8. Celce-Murcia, M., Brinton, D., Snow, M. (2014). Teaching English as a Second or Foreign Language ( $4^{\text {th }}$ Ed.). Boston.: National Geographic Learning; Heinle, Cengage Learning.

9. Fang, F. (2010). A Discussion on Developing Students' Communicative Competence in College English Teaching in China. Journal of Language Teaching and Research. 2, 111 - 116. Retrieved from

http://www.academypublication.com/issues/past/jltr/vol01/02/02.pdf

10. Gilakjani, A. (2012). A study of factors affecting EFL learners' English pronunciation learning and the strategies for Instruction. International Journal of Humanities and Social Sciences, 3, 119-128. Retrieved from

http://www.ijhssnet.com/journals/Vol_2_No_3_February_2012/17.pd $\mathrm{f}$

11. Hrehová, D. (2010). The Significance of Communication and Language Competences for Employment and Career Development. Human Resources Management \& Ergonomics. 4, 5769. $\quad$ Retrieved from http://fim2.uhk.cz/hed/images/KOMPLET_2_AG.pdf

12. Hu, Z. (2014). Study on Developing Chinese College EFL Learners' Pragmatic Competence in Relation to Language Proficiency and Overseas Experience. Journal of Language Teaching and Research, 5, pp. 391-398. doi:10.4304/j1tr.5.2.391-398 
13. Larsari, V. N. (2011). Learners' Communicative competence in English as a Foreign Language (EFL). Journal of English and literature, 2, 161-165. Retrieved from http://www.academicjournals.org/journal/IJEL/article-full-textpdf/7C380B61342

14. MacLeod, F., \& Larsson, P. (2011). Exposure to English outside the Classroom (Degree project). Available from Malmö University Electronic Publishing.

15. McLeod, S. (2014). Lev Vygotsky. Retrieved from www.simplypsychology.org/vygotsky.html

16. Mitib, M. (n.d.) Pragmatic Competence and Pragmatic Instruction in Classroom Oral Communicative Activities. Retrieved from: http://qu.edu.iq/agr/wp-content/uploads/Pragmatic-Competence-andPragmatic-Instruction-in-Classroom-Oral-Communicative-Activities.pdf

17. Nouar, Y. (n.d). Linguistic competence, communicative competence, pragmatic competence and their implications for foreign language teaching and testing. Retrieved from: /Linguistic\%20competence\%20communicative \%20competence\%20p ragmatic\%20competence $\% 20$ and $\% 20$ their $\% 20$ implications $\% 20$ for $\%$ 20 foreign $\% 20$ language $\% 20$ teaching $\% 20$ and $\% 20$ testing-1.pdf

18. Rodriques, M. (2000). A Perspective of Communication and Communicative Competence. Concept Publishing Company, New Delhi. Retrieved from https://books.google.com.mx/books?id=SAwQn7communicative+co mpetence\&hl=es-419\&sa $=X \&$

19. Saville-Troike, M. (2005). Introducing Second Language Acquisition in Introducing Second Language Acquisition (pp. 1-6). Retrieved from https://books.google.com.mx/books/about/Introducing_Second_Lang uage_Acquisition.html?id=fw1uXo6P9LEC\&redir_esc $=\mathrm{y}$

20. Shinde, B. \& Shavan, S. (2013). Development of Communicative Competence in Students. International journal of advanced scientific and technical research, 3, 152-161. Retrieved from http://www.rspublication.com/ijst/index.html

21. Wilson, S. R. \& Sabee, C. M. (2003). Explicating communicative competence as a theoretical term. In J. O. Greene \& B. R. Burleson, Handbook of communication and social interaction skills (pp. 3-50). Mahwah, NJ: Lawrence Erlbaum.

22. Yufrizal, H. (2014). Teachers and Students' Perceptions of Communicative Competence in English as a Foreign Language in Indonesia. Journal of Language Teaching and Research, 23, 16-33. 
Retrieved

from

http://artikel.ubl.ac.id/index.php/icel/article/view/248/784 